\title{
Thidiazuron-induced high-frequency shoot regeneration from root region of Robinia pseudoacacia L. seedlings
}

\author{
M. HOSSEINI-NASR and A. RASHID* \\ Department of Botany, University of Delhi, Delhi-110007, India
}

\begin{abstract}
High-frequency regeneration of shoots was achieved at root region of seedlings of Robinia pseudoacacia L. cultured from seeds on medium supplemented with thidiazuron (TDZ, $1.0 \mu \mathrm{M}$ ). The roots of intact seedlings proliferated and formed a compact callus followed by differentiation of numerous shoots. Corresponding cultures on benzylaminopurinecontaining medium exhibited much weaker response. Hypocotyl segments also formed shoots at a lower concentration of TDZ $(0.1 \mu \mathrm{M})$. The shoots formed on TDZ-containing medium were well-developed and readily rooted on hormonefree medium. The obtained plants after acclimation in culture room survived after transfer to soil.
\end{abstract}

Additional key words: acclimation, black-locust, seed culture.

The black-locust (Robinia pseudoacacia L.), a multipurpose nitrogen-fixing member of Leguminosae, is one of the most quickly growing trees cultivated throughout the world for its timber, firewood, fodder, honey, soil-conservation and erosion-control. In view of its economic importance and desirability of elite plants, $R$. pseudoacacia has been subjected to extensive as well as intensive studies of in vitro regeneration. Many efforts have been made to regenerate this tree from different explants.

Attempts to micropropagate this tree, employing either benzylaminopurine (BAP) or thidiazuron (TDZ), are slow with poor yield (Chalupa 1983, 1987, Barghchi 1987, Davis and Keathley 1987). Shoots regenerated from callus cultures on auxin and cytokinin-containing medium are tree-specific (Han et al. 1993) and are to be tested for their fidelity; particularly in view of their lack of rooting response (Enescu and Jucan 1985). Regeneration through somatic embryogenesis, although a preferred mode of regeneration due to the presence of preformed shoot- and root-pole in an embryo, is possible from immature embryos and occurs in a low frequency (Arrillaga et al. 1994). Moreover, an immature embryo as an explant involves not only a tedium of isolation but is also constrained in its availability. This communication describes a relatively simple method of high-frequency regeneration of shoots due to TDZ-treatment of seedlings and seedling explants. The present regeneration system was aimed to be rapid, reproducible and prolific in comparison with BAP-induced shoot formation.

Sun-dried seeds of Robinia pseudoacacia L. collected from mature fruits in northern Iran, were scarified with $3.6 \mathrm{M} \mathrm{HCl}$ for $30 \mathrm{~min}$, washed thoroughly with sterile distilled water (SDW), sterilized in $0.5 \%$ solution of mercuric chloride for $20 \mathrm{~min}$, rinsed repeatedly in SDW and placed on nutrient medium for germination. The mineral formulation $\mathrm{N}_{6}$ (Chu et al. 1978) was solidified with $0.8 \%$ agar (Difco, Bacto) and supplemented with $2 \%$ sucrose and BAP $(0.1-1.0 \mu \mathrm{M})$ or TDZ $(0.1-1.0 \mu \mathrm{M})$. The cultures were maintained at $25 \pm 2{ }^{\circ} \mathrm{C}$ under

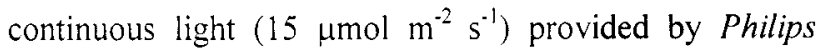
fluorescent tubes. The experiments were repeated many times with identical results. At least $30-40$ cultures were raised for each treatment. The plantlets formed in vitro were washed out of agar medium by keeping for $4 \mathrm{~h}$ in distilled water and occasional shaking. These plantlets were transferred to pots containing autoclaved Soilrite (vermiculite) moistened with half-strength Murashige and Skoog's nutrients and the entire set-up was covered with polythene to provide a near-sterile high-humidity environment. After one week, the polythene was removed and plantlets were transferred to garden soil in pots.

Received 12 August 2002. accepted 17 August 2003.

Abbreviations: BAP - benzylaminopurine. IBA - indole-3-butyric acid, NAA - $\alpha$-naphthaleneacetic acid, TDZ - thidiazuron (N-phenyl-N'-1.2,3-thiadiazol-5-yl urea).

* Corresponding author; fax: (+91)27667573, e-mail: arashid_du@hotmail.com 
The scarified seeds cultured on hormone-free medium showed signs of germination within $3 \mathrm{~d}$ and formed complete seedlings after $10 \mathrm{~d}$. The first noticeable change, observed on medium supplemented with $1.0 \mu \mathrm{M}$ TDZ after an initial process of germination, was an arrested growth of seedlings in general and of
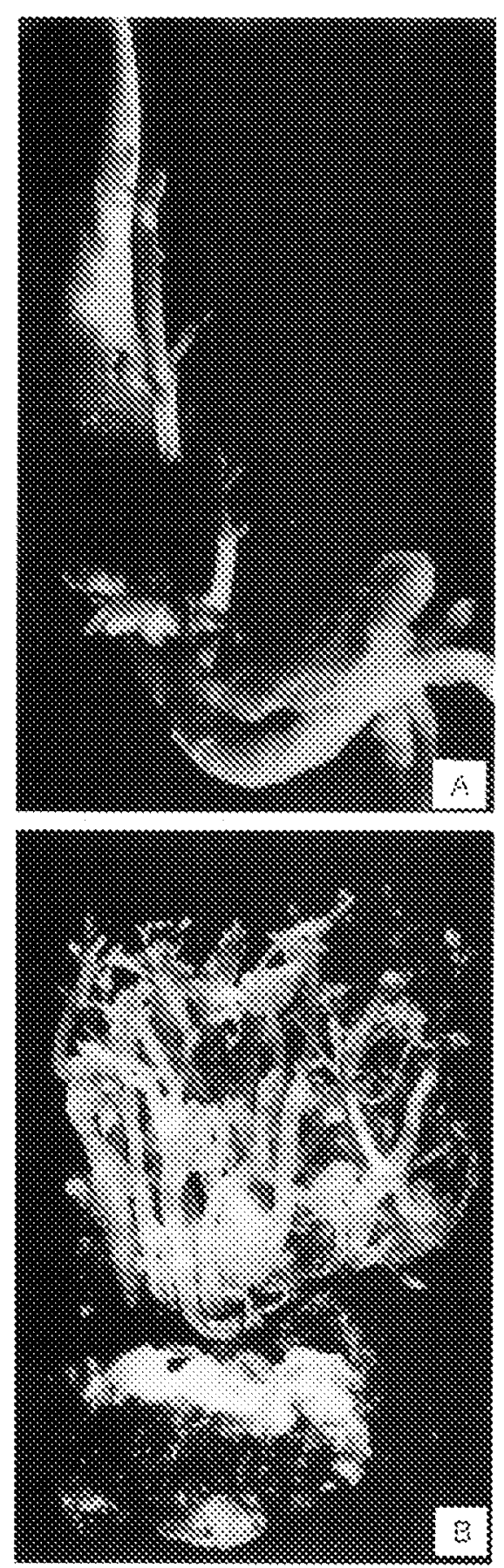

Fig. 1. Robinia pseudoacacia seedling on medium with $1.0 \mu \mathrm{M}$ TDZ. $A$ - lower portion of a seedling showing early stage of callusing from root region and differentiation of a couple of shoots: $B$ - numerous shoots differentiated on root region of a seedling within $30 \mathrm{~d}$ of culture. root-system in particular. In $30 \%$ of these seedlings, internal proliferation of root and formation of a few shoots directly on it (Fig. $1 A$ ) were observable within one week of seed germination. In due course the frequency of such seedlings increased to more than $50 \%$ of cultures and finally in all cultures (Table 1) the formation of a compact callus was followed by differentiation of numerous shoot-buds. Within one month of culture these shoot-buds elongated to form shoots (Fig. 1B). A decline in response to $20 \%$ of the cultures was found at a lower concentration of $\mathrm{TDZ}(0.5 \mu \mathrm{M})$. At $0.1 \mu \mathrm{M}$ of TDZ the proliferation of root system did not result in either callus or shoot formation.

Table 1. Effect of TDZ and BAP on regeneration of Robinia pseudoacacia

\begin{tabular}{lllll}
\hline Explant & Hormone & $\begin{array}{l}\text { Conc. } \\
{[\mu \mathrm{M}]}\end{array}$ & $\begin{array}{l}\text { Response } \\
{[\%]}\end{array}$ & $\begin{array}{l}\text { Number of shoots } \\
{\left[\text { culture }^{-1}\right]}\end{array}$ \\
\hline Seed & TDY & 1.0 & 100 & $54.0 \pm 5.25$ \\
& TID\% & 0.5 & 20 & $13.0 \pm 2.53$ \\
& BAP & 1.0 & 8 & $2.8 \pm 0.23$ \\
& BAP & 0.5 & 0 & 0 \\
Hypocotyl TDZ & 0.1 & 75 & $9.1 \pm 0.71$ \\
& TDZ & 1.0 & 58 & $5.5 \pm 0.45$ \\
& BAP & 0.1 & 10 & $2.0 \pm 0.85$ \\
& BAP & 1.0 & 36 & $5.0 \pm 0.38$ \\
\hline
\end{tabular}

Hypocotyl explants $(1 \mathrm{~cm})$ from seedlings developed on hormone-free medium also formed shoots on medium containing TDZ. At a low concentration of TDZ $(0.1 \mu \mathrm{M})$, formation of calli in about $25 \%$ cultures and direct shoot formation in the remaining cultures $(75 \%)$ were observed within $20 \mathrm{~d}$. The shoots originated as a result of de novo meristematic activity. On average, nine shoots developed per explant. At a higher concentration of TDZ $(1.0 \mu \mathrm{M})$ this response declined to $60 \%$ of the cultures with an average of five shoots per explant.

A comparison of these results was performed with corresponding cultures on BAP-containing medium (Table 1). The seedlings developed on medium with $0.1 \mu \mathrm{M}$ BAP were normal, without any change in morphology. At $1.0 \mu \mathrm{M}$ BAP, the lower portion of seedlings formed calli, which was followed by formation of 2 - 3 shoot-buds per culture. Hypocotyl segments also produced shoots on medium with BAP. With increasing concentration of BAP from 0.1 to $1.0 \mu \mathrm{M}$ there was an increase in callusing along with a corresponding enhancement in frequency of cultures showing shoot formation as well as in the number of shoots per explant. At $1.0 \mu \mathrm{M}$ BAP about 5 shoots were formed per explant.

Shoots developed on roots of intact seedlings or hypocotyl explants in response to TDZ or BAP were well-developed and readily rooted in $70 \%$ cultures on hormone-free medium. Inclusion of NAA $(0.5,1.0$ and 
$2.5 \mu \mathrm{M})$ or IBA increased this frequency of rooting to $90 \%$ of cultures. After an acclimation in culture room, these plants survived the transfer to soil.

The regeneration of a few shoots on roots of seedlings of $R$ pseudoacacia in response to BAP and numerous shoots in response to TDZ, reported here represents a new system for rapid regeneration. Utility of seed as an explant allows experimentation all the year round and reduces the optimization of many factors such as size, physiological age and orientation of explant which are crucial for the success of regeneration in general and of legumes in particular (Lazzeri et al. 1987, Nef-Campa et al. 1996). TDZ-induced shoot formation on roots of seedlings of Albizzia julibrissin was reported previously (Sankhla et al. 1994, Hosseini-Nasr and Rashid 2002). In addition to shoot formation on root region, the hypocotyl segments of $R$. pseudoacacia also readily formed shoots in response to TDZ. In previous literature shoots formed in response to $T D Z$ were reported to remain stunted (Chalupa 1987, Preece and Imoel 1991, Huetteman and Preece 1993, Sankhla et al. 1994). Interestingly this is not

\section{References}

Arrillaga, I., Tobolski, J.J.. Merkle, S.A.: Advances in somatic embryogenesis and plant production of black locust (Robinia pseudoacacia L.). - Plant Cell Rep. 13: 171-175. 1994.

Barghchi, M.: Mass clonal propagation in vitro of Robinia pseudoacacia L. (black locust) cv. Jaszkiseri. - Plant Sci. 53: 183-189, 1987.

Beattie, L.D., Garrett, R.C.: Adventitious shoot production from immature embryos of white clover. - Plant Cell Tissue Organ Cult. 42: 67-73, 1995.

Chalupa, V.: In vitro propagation of willows (Salix spp.), European mountain ash (Sorbus aucuparia L.) and black locust (Robinia pseudoacacia L.). - Biol. Plant. 25: 305307, 1983.

Chalupa, V.: Effect of benzylaminopurine and thidiazuron on in vitro shoot proliferation of Tilia cordata Mill, Sorbus aucuparia L. and Robinia pseudoacacia L. - Biol. Plant. 29: 425-429, 1987.

Chu, C.C.: The $\mathrm{N}_{6}$ medium and its applications to anther of cereal crops. - In: Proceedings of the Symposium on Plant Tissue Culture. Pp. 43-50. Sci. Press, Beijing 1978.

Davis, J.M., Keathley, D.E.: Differential responses to in vitro bud culture in mature Robinia pseudoacacia L. (black locust). - Plant Cell Rep. 6: 431-434, 1987.

Enescu, V.. Jucan, A.: Problems of in vitro micropropagation of black locust (Robinia pseudoacacia). - In: Symposium on in vitro Problems Related to Mass Propagation of Horticultural Plants. P. 11. Int. Soc. Hort. Sci., Gembloux 1985.

Han, K.H., Keathley, D.E., Gordon, M.P.: Cambial tissue culture and subsequent shoot regeneration from mature black locust (Robinia pseudoacacia L.). - Plant Cell Rep. 12: 185-188, 1993.

Heutteman, C.A., Preece, J.E.: Thidiazuron: a potent cytokinin for woody plant tissue culture. - Plant Cell Tissue Organ the case in black-locust as shown in the present investigation.

The reason for remarkable efficiency of TDZ vs BAP in regeneration remains to be resolved. TDZ, a phenylurea derivative exhibits a high morphogenic potential in a diverse array of responses ranging from proliferation of cytokinin-requiring tissue (Mok et al. 1987, Thomas and Katterman 1986) to induction of shoot-buds (Thomas and Katterman 1986) and somatic embryos (Hutchinson et al. 1996, Iantcheva et al. 1999). It promotes shoot regeneration on seedlings of herbaceous as well as woody species (Huetteman and Preece 1993, Liu 1993, Murthy et al. 1998). Significantly, it is also effective in regeneration of recalcitrant system such as grain legume (Malik and Saxena 1992). As for mode of action of TDZ at morphological level, it induces an increase in number of meristematic centres on the treated tissue (Beattie and Garrett 1995, Hutchinson et al. 1996), also demonstrated in this investigation.

Cult. 33: 105-119, 1993

Hosseini-Nasr. M.. Rashid, A.: Thidiazuron-induced shoot-bud formation on root segments of Albizzia julibrissin is an apex-controlled, light independent and calcium-mediated response. - Plant Growth Regul. 36: 81-85, 2002.

Hutchinson, M.J., Krishnaraj, S., Saxena, P.K.: Morphological and physiological changes during thidiazuron-induced somatic embryogenesis in geranium (Pelargonium $x$ hortorum Bailey) cultures. - Int. J. Plant Sci. 157: 440-446. 1996.

Iantcheva, A., Vlahova, M., Bakalova, E., Kondorosi, E., Elliott, M.C., Attansova, A.: Regeneration of diploid annual medics via direct somatic embryogenesis by thidiazuron and benzylaminopurine. - Plant Cell Rep. 18: 904-910, 1999.

Lazzeri, P.A., Hildebrandt, D.F., Collins, G.B.: Soybean somatic embryogenesis: effects of nutritional. physical and chemical factors. - Plant mol. Biol. Rep. 10: 209-220, 1987.

Liu, C.Y.: The use of thidiazuron in tissue culture. - In Vitro cell. dev. Biol. 29: 92-96, 1993.

Malik, S.A., Saxena, P.K.: Regeneration in Phaseolus vulgaris L. High frequency induction of direct shool formation in intact seedlings by $\mathrm{N}^{6}$-benzylaminopurine and TDZ. Planta 186: 384-389, 1992.

Mok, M.C., Mok, D.W.S., Turner, J.E., Mujer, C.V.: Biological and biochemical effects of cytokinin-active phenylurea derivatives in tissue culture systems. - Hort. Sci. 22: $1194-$ 1197, 1987.

Murthy, B.N.S., Murch, S.J., Saxena, P.K.: Thidiazuron a potent regulator of in vitro plant morphogenesis. - In Vitro cell. dev. Biol. Plant 34: 267-275, 1998.

Nef-Campa, C., Chaintreuil-Dongmo, C., Drefyus, B.L.: Regencration of tropical legume Aeschynomene sensitiva Sin. from root explants. - Plant Cell Tissue Organ Cult. 44: 149-154, 1996.

Preece, J.E., Imoel, M.R.: Plant regeneration from leaf explants 
of Rhododendron. - Sci. Hort. 48: 159-170, 1991.

Sankhla, D., Davis, T.D., Sankhla, N.: Thidiazuron-induced in vitro shoot formation from roots of intact seedlings of Albizzia julibrissin. - Plant Growth Regul. 14: 267-272,
1994.

Thomas, J.C., Katterman, F.R.: Cytokinin activity induced by thidiazuron. - Plant Physiol. 81: 681-683, 1986. 